\title{
Linking land subsidence to soil types within Hue city in Central Vietnam
}

\author{
Liên kết giữa sụt lún với các loại đất ở thành phố Hue miền Trung Việt Nam
}

\author{
BRAUN, Andreas ${ }^{*}$; HOCHSCHILD, Volker; PHAM, Tung Gia ${ }^{2} ;$ NGUYEN, Linh Hoang Khanh³; \\ BACHOFER, Felix ${ }^{4}$
}

'University of Tübingen, Rümelinstraße 19-23, 72072 Tübingen, Germany; ${ }^{2}$ University of Agriculture and Forestry, Hue University, 102 Phung Hung Street; Hue City, Vietnam; IInternational School, Hue University, 04 Le Loi, Hue City, Vietnam; ${ }^{4}$ German Aerospace Center (DLR), Münchener Str. 20, 82234 Wessling, Germany

\begin{abstract}
Coastal areas of Southeast Asia are progressively threatened by flooding as a consequence of more frequent precipitation extremes and rising sea levels. Especially urban areas are affected by flood risk which is additionally increased by surface subsidence related to building activities and groundwater extraction. However, the severity of subsidence as well as its triggers and environmental interrelations are only little understood. This study measures surface subsidence for Hue city by using persistent scatterer radar interferometry (PS-InSAR). A series of 53 images acquired by the Sentinel-1 radar satellite between 2018 and 2019 was analyzed to reliably retrieve surface changes at the millimeter scale. The overall displacement ranges between -25 and +10 millimeters per year. Its spatial distribution was then compared to the extent of different soil types in the study area to conduct an analysis of variance (ANOVA). The results confirmed a significant difference between the soil types with Plinthic Acrisols as the soil type having the largest negative average surface velocity. Possible triggers are the intrusion of slack water from the surrounding rice cultivation areas and construction activities which lead to increasing weight and soil compaction. The findings shall raise awareness for the topic and underline the demand for further research.
\end{abstract}

Tóm tắt. Mưa lớn và nước biển dâng là những nguyên nhân gây lũ lụt ngày càng nghiêm trọng ở các khu vực ven biển Đông Nam Á. Đặc biệt việc gia tăng công trình xây dựng và khai thác nước ngầm gây sưt lún bề mặt dẫn đến ngập lưt ở các vùng đô thị. Tuy nhiên, các nghiên cứu về mối tương quan giữa sưt lún bề mặt với các hiện tượng môi trường chưa được chú trọng nhiều. Trong nghiên cứu này, độ lún bề mặt của thành phố Hue được đo bằng phương pháp giao thoa radar tán xạ liên tục (PS-InSAR). Phân tích 53 ảnh vệ tinh Sentinel-1 từ năm 2018-2019 cho thấy sự thay đổi tổng thể bề mặt dao động từ -25mm đến $10 \mathrm{~mm}$ mỗi năm. Phân tích phương sai (ANOVA) cho thấy sự thay đổi bề mặt khác nhau tùy từng loại đất, trong đó đất đỏ vàng (Plinthic Acrisols) có tốc độ sụt lún trung bình cao nhất. Các tác nhân có thể là do sự xâm nhập của nước từ các vùng trồng lúa xung quanh và các hoạt động xây dựng dẫn đến tăng trọng lượng và nén đất. Những phát hiện này là cơ hội nâng cao nhận thức về sự sụt lún bề mặt và cần được nghiên cứu thêm.

Keywords: ground subsidence; InSAR; risk assessment; coastal areas; radar satellites

\section{Introduction}

\subsection{Subsidence in coastal areas}

Land subsidence is defined as the lowering of the land surface by mass movement and can be considered a globally relevant phenomenon with extensive socioeconomic impacts (Holzer, 1984). However, compared to other environmental issues, such as air pollution or waste management, subsidence is still underrepresented in both public debates and scientific research, especially in Asian coastal cities (Kaneko \& Toyota, 2011; Karegar et al., 2018). It has drawn increasing attention in the past decades, because it has been proven to increase the flood vulnerability of coastal cities concerning flood frequency, inundation depth, and duration, especially in combination with the impacts of sea-level rise (Erkens et al., 2015). In most Southeast Asian cities, land subsidence in urban areas is triggered by heavy groundwater extraction (Minderhoud et al., 2017) and illogical urban planning and construction activities, but also fostered by geological settings where alluvial sediments and high groundwater levels get together, as it is the case in the Mekong Delta (Nguyen, 2016). Monitoring of subsidence rates and their spatial patterns is therefore a key task in Southeast Asian coastal cities to promote coping measures and to ensure the future well-being of their population (Takagi, Thao, \& Le Anh, 2016). The presented study investigates surface subsidence in the city of Hue, Central Vietnam, in relation 
to soil types to initiate the future development of adapted measures of disaster risk reduction.

\subsection{Current state of research}

Direct methods of measuring subsidence combine conventional and differential global positioning system (GPS and D-GPS), numerical modelling, and spirit-levelling surveying (Gambolati, Teatini, \& Ferronato, 2005). This has been successfully demonstrated by Thu and Fredlund (2000) who modelled a subsidence of 20-35 millimetres per year [mm/a] for the central and south-eastern part of Hanoi. However, field measurements are expensive and can only be conducted for a limited amount of selected locations. In the last decades, spaceborne approaches measuring surface changes by differential radar interferometry (DInSAR) have therefore gained considerable popularity, because they offer a systematic and objective way of measuring changes of the earth's surface at the centimetre scale (Strozzi et al., 2001). This technique compares the phase information of two microwave image to derive surface displacements which occurred between the two acquisitions, and has been successfully applied in numerous cases (Ketelaar et al., 2009). However, this approach is limited over surfaces with rapidly changing surface characteristics, such as vegetation and water bodies which lead to decorrelation of the phase information, potentially introducing errors in the displacement maps (Zebker \& Villasenor, 1992). To mitigate this error source permanent (or persistent) scatterer radar interferometry (PS-InSAR) has been developed which identifies surfaces with stable phase information and performs displacement mapping only on these pixels in the image (Ferretti, Prati, \& Rocca, 2001). This reduces potential error sources and makes the subsidence estimates more precise. However, it relies on a larger number of radar acquisitions to compute multiple image pairs. PS-InSAR has been applied by Minh, van Trung, and Toan (2015) for Ho Chi Minh City using ALOS radar data between 2006 and 2010 and indicated an average subsidence rate of $8 \mathrm{~mm}$ per year. Especially along the Sai Gon river and in the southwest of the city, the land has sunk up to $12 \mathrm{~cm}$ in four years. As the main reason, they name the groundwater extraction under the city. Similar studies have been conducted for the city of Hanoi, based on ALOS (Dang et al., 2014), TerraSAR-X (Anh et al., 2019; Le et al., 2016) and Sentinel-1 (Hao \& Takewaka, 2019). All report lowering of groundwater as one reason, furthermore unsaturated layers and the increase of builtup weight. All report an average subsidence rate of 15-25 $\mathrm{mm} / \mathrm{a}$, but some areas reach up to $68 \mathrm{~mm} / \mathrm{a}$. As a relevant study outside Vietnam, Catalao, Raju, and Nico (2020) predict an increase of $25 \%$ in the flood area in the central area of Singapore based on PS-InSAR measurements of TerraSAR-X for the predicted climate change scenarios.

No study on subsidence has been carried out in the Thua Thien-Hue province, whose UNESCO World Heritage sites (e.g. the imperial city in the capital) are exposed to flooding hazards from both the hinterlands of the Perfume River (Hương Giang) catchment and the seaside (Hien et al., 2005).

\section{Methods and results}

\subsection{Study area and data}

The city of Hue is located in the Thua Thien-Hue province in Central Vietnam (Figure 1A), approximately 10 kilometres from the coast. It is divided by the Perfume River (Hương Giang) into a north-western part, mostly dominated by the structure of the Imperial City, and the more urbanized south-eastern part (Figure 1 B and C). Because of its location both close to the coast and at the lower part of the river's catchment, it is regularly affected by flash floods and surging seawater and these threats are likely to increase with climate change in the future (Tien Thanh \& Dutto Aldo Remo, 2018) To investigate surface subsidence as a possible contributor to coastal flooding, a series of 53 radar images of Sentinel- 1 was used in this study, acquired between January 2018 and October 2019 in descending mode of relative orbit 18. The image acquired on 02.11.2018 was selected as the master for the co-registration of image pairs (each of the 52 remaining images, also called 'slaves', with the master image) and the computation of interferograms as the base information of surface displacement using the Python-based framework provided by Delgado Blasco and Foumelis (2018). The surface displacement was then calculated based on the Stanford Method for Persistent Scatterers (StaMPS) initially proposed by Hooper et al. (2004) and later released as open software toolkit for InSAR processing (Hooper et al., 2018). This resulted in a total of 126,289 persistent scatterers (PS), mainly distributed over solid surfaces in the study area (Figure 1C). Information over rice fields or areas which underwent significant changes during the investigated period cannot be retrieved because of the decorrelation of the phase signal. Each PS allows the derivation of an average velocity in millimetres per year $[\mathrm{mm} / \mathrm{a}]$, where positive values indicate movement of the surface towards the sensor while negative values indicate subsidence along the line of sight.

A second source of information is a digital soil map at the scale of 1:100,000 that was created by National Institute of Agricultural Planning and Projection of Vietnam (NIAPP) in 2005. Initially, it contains 15 soil types in the Thua Thien Hue province, of which eight lay within the study area (Figure 1B, red polygon). It was combined with the information on displacement retrieved from the PS InSAR measurements by spatial intersection.

\subsection{Results and discussion}

The spatial distribution of surface velocities between 01/2018 and 10/2019 is shown in Figure 1C. It indicates at first glance, that the majority of PS lies within a neglectable range of -5 and $+5 \mathrm{~mm} / \mathrm{a}$ which can be considered as no 
surface movement. However, there are some patterns which suggest a correlation with the different soil types, for example, the road in the northwest of the city, which is dominated by large subsidence. It coincides with the extent of the Plinthic Acrisols but this visual indication will be examined statistically in the following.

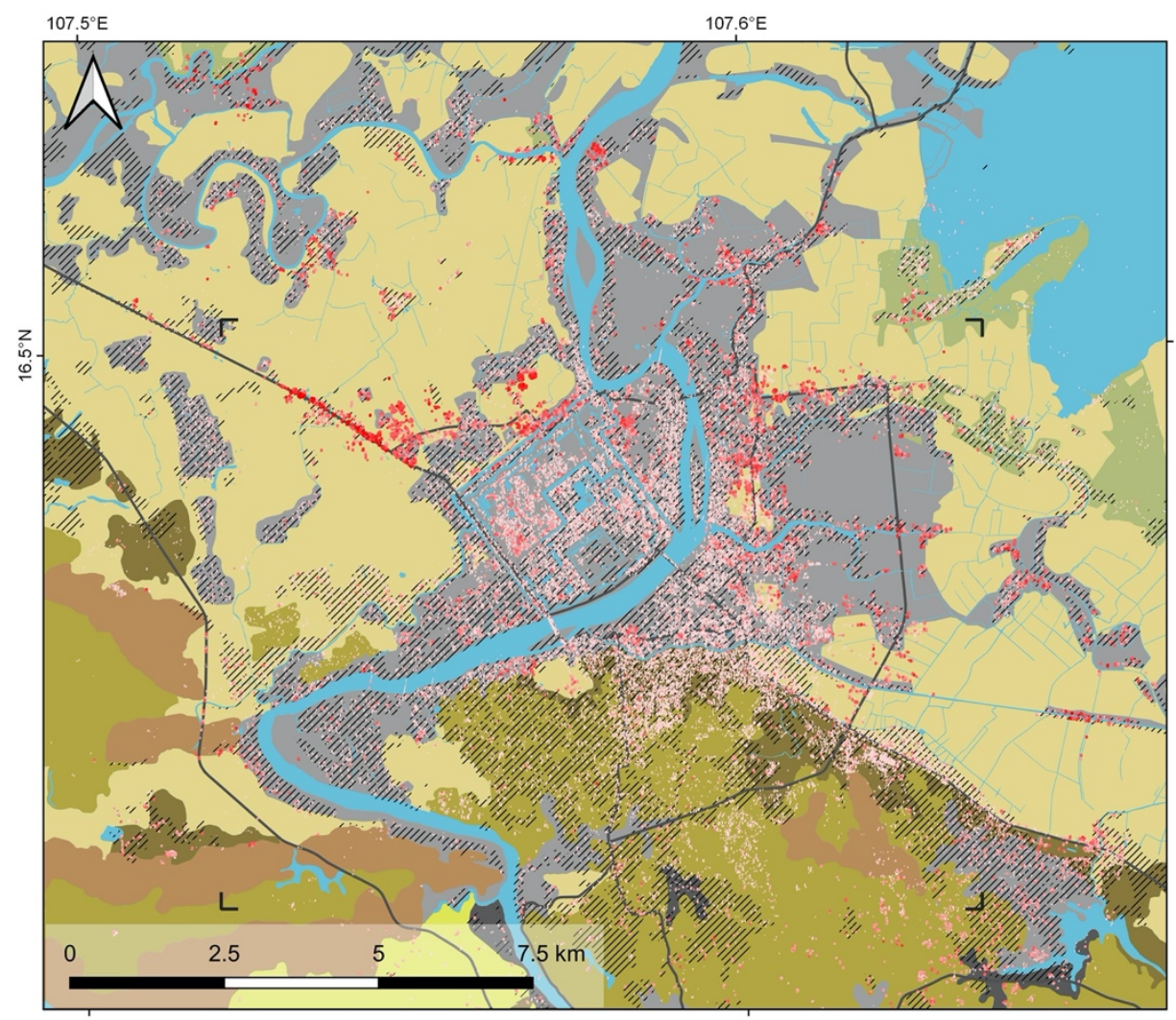

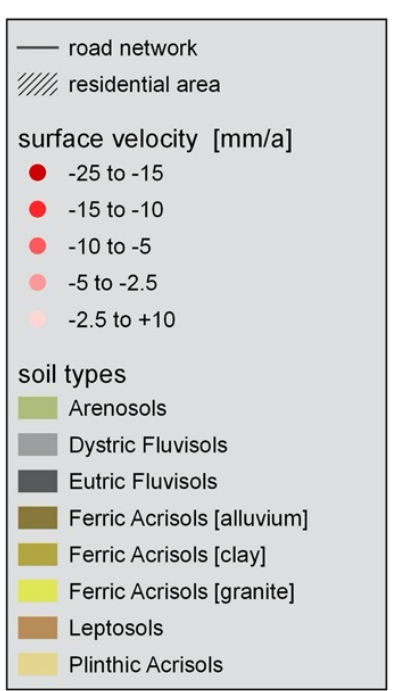

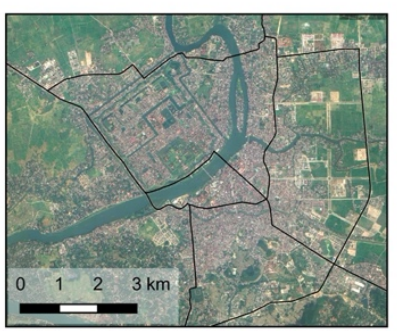

\section{Figure 1. Location of the study area in Southeast Asia (A), extent of the study area (B), and spatial surface subsidence patterns}

In the first step, all displacement values of PS within a soil type were statistically aggregated. Table 1 shows that Plinthic Acrisols (Ap), Dystric Fluvisols (Jd) and Ferric Acrisols [clay] (Af-c) make up around $84 \%$ of the soils in the study area and contain the same percentage of PS, accordingly. It furthermore indicates that there are considerable differences in the average velocity (vel [avg]) of the soil types on the one side; on the other side, Leptosols (I), Ferric Acrisols [granite] (Af-g), and Eutric Fluvisols (Je) are under-represented in the study area and contain only 1441 PS (1.1\%), so their average displacements should be handled with care. However, Arenosols (Q), Ferric Acrisols [alluvial] (Af-a), Ferric Acrisols [clay] (Af-c), Plinthic Acrisols (Ap), and Dystric Fluvisols (Jd) reveal strong velocity variations in the study area. As shown in Figure 2, Ap and Je have clear negative means while Af-c and Jd have averages around zero. The large standard deviation of Ap (vel [std] = 4.2) indicates that this soil type has a generally large range of velocities, probably because of its high spatial abundance (37\% of the study area).

As indicated in Figure 1, the spatial occurrence of Plinthic Acrisols (indicated by the point signature), which have the largest occurrence in the study area, is linked to rice cultivation, which means that they are periodically or permanently affected by slack water. Their high clay content makes them particularly vulnerable to shrinking and swelling dynamics according to the moisture content, thus increasing the risk for land subsidence (Thu \& Fredlund, 2000).

The second most frequent soil type (Dystric Fluvisols, indicated by horizontal line signature), are concentrated in the urban area and characterized by little deformation. They are related to alluvial deposits which concentrate in this area where the Huong River meets the shoreline. But especially at their border to other soil types, such as in the northeast of the city, high velocities occur.

Ferric Acrisols mainly occur in the hinterland of the city (vertical line signature) and are also characterized by very little surface velocities as well as comparably low standard deviations. This soil type seems to have high stability, but it is also only little used for construction so far.

The positive average velocity of Arenosols (solid grey signature) indicates a relative uplift of areas along the shoreline, potentially a relative compensation of the subsiding inland areas. However, their low spatial representation does not allow larger interpretation. 
Table 1. Average (avg), minimum (min), maximum (max), and standard deviation (std) of surface velocity per soil type

\begin{tabular}{|c|c|c|c|c|c|c|c|}
\hline Soil type [substrate] & short & area [ha] & area [\%] & PS [n] & PS [\%] & vel [avg] & vel [std] \\
\hline Plinthic Acrisols & Ap & 8,549 & $36.9 \%$ & 17,143 & $13.6 \%$ & -1.5 & 4.2 \\
\hline Dystric Fluvisols & $J d$ & 6,444 & $27.8 \%$ & 72,670 & $57.5 \%$ & -0.1 & 2.6 \\
\hline Ferric Acrisols [clay] & $A f-c$ & 4,538 & $19.6 \%$ & 16,587 & $13.1 \%$ & 0.2 & 2.3 \\
\hline Leptosols & I & 1,363 & $5.9 \%$ & 673 & $0.5 \%$ & -0.4 & 2.7 \\
\hline Ferric Acrisols [alluvial] & Af-a & 914 & $4.0 \%$ & 14,355 & $11.4 \%$ & 0.7 & 1.8 \\
\hline Arenosols & $\mathrm{Q}$ & 806 & $3.5 \%$ & 4,093 & $3.2 \%$ & 1.3 & 2.6 \\
\hline Eutric Fluvisols & Je & 254 & $1.1 \%$ & 479 & $0.4 \%$ & -1.5 & 1.9 \\
\hline Ferric Acrisols [granite] & Af-g & 296 & $1.3 \%$ & 289 & $0.2 \%$ & -1.6 & 2.2 \\
\hline
\end{tabular}

\section{Boxplot grouped by soiltype}

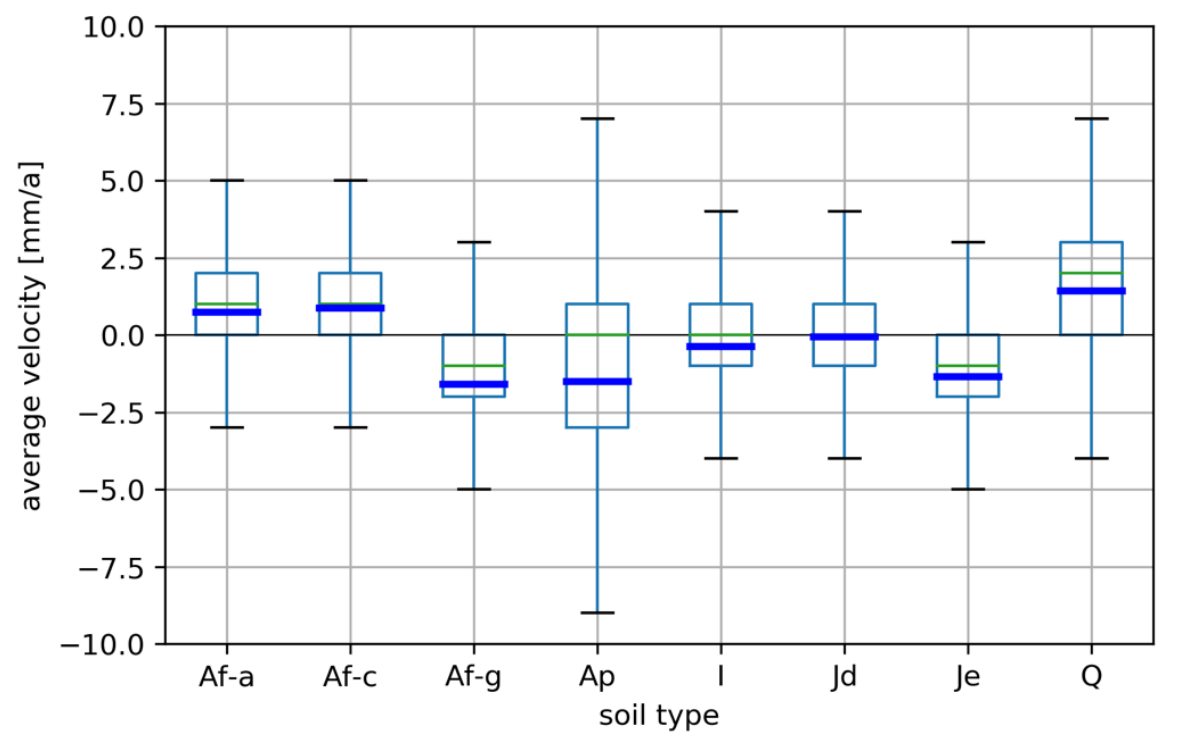

Figure 2. Variation of surface velocities by soil type in the study area (medians in green, means in blue)

To statistically test for significance, a one-way analysis of variance (ANOVA, Fisher, 1954) was conducted in a second step, using the soil types as the categorical variables and the surface velocities retrieved from the PS as the dependent target variable. The basic assumptions, namely independence of observations, normal distributions of the residuals, and homogeneity of variances are given in this case and were tested accordingly (Snedecor \& Cochran, 1967). The analysis resulted in a probability value $p<0.001$ which means that there is a highly significant variation between the different soil types which is not caused by chance. A subsequent post-hoc test based on honestly significant differences (HSD, Tukey, 1949) revealed, that there is no significant difference in surface velocity between Plinthic Acrisols and Ferric Acrisols [granite] ( $p=$ 0.99), Eutric Fluvisols and Ferric Acrisols [granite] ( $p=0.94)$, as well as between Plinthic Acrisols and Eutric Fluvisols $(p=0.96)$. This underlines that not enough PS lay within Ferric Acrisols [granite] and Eutric Fluvisols and that the variation within Plinthic Acrisols is probably linked to additional factors. In turn, all other pairwise combinations of soil types $(n=25)$ show probability values of $p<0.001$, which allows the overall conclusion that soil types in and around the city of Hue significantly differ regarding the observed surface displacement velocities. The observed remaining variance has to be analysed in further studies.
As suggested by other studies of coastal cities in Southeast Asia, the factor of increasing construction weight and traffic of heavy trucks in areas of urban development has to be considered as an additional trigger (Dang et al., 2014; Hao \& Takewaka, 2019; Le et al., 2016). This is furthermore supported by the pattern of largest subsidence along major roads.

\section{Outlook}

Results of this study indicate that there is a correlation between surface subsidence and soil types in the coastal area of the Thua Thien-Hue province in Central Vietnam. Especially the spatial distribution of Plinthic Acrisols seems to correlate with high subsidence rates. Such information are of peculiar interest against the background of rising sea levels, and increasing climatic extreme events and challenges of land management of coastal areas. However, results of this study have to be investigated and confirmed by further research. To increase the scientific robustness, the following points should be addressed: 1) A longer timeseries of radar images could be analysed (Sentinel-1 was launched in late 2014) to get a longer and more stable series of persistent scatterer phase information. Additionally, information on ascending and descending 
passes can be combined as suggested by Strozzi et al. (2001). This allows the derivation of vertical displacements instead of the analysis of elevation change along the sensor's line of sight. To get even more reliable results, the small baseline (SBAS) concept can be applied which allows more combinations of image pairs for a larger number of usable interferograms (Minh et al., 2015).

From a thematic perspective, further factors contributing to soil compaction and surface subsidence should be integrated in the future. For example, the impact of increasing construction weight could be approximated by extracting the built-up areas from time-series of satellite images. The amount of change per defined area can then also be correlated with the average surface displacement to test if areas with a stronger increase of built-up areas also show larger surface subsidence. So, the analysis of variance conducted in this study could be extended to a multivariate ANOVA, determining the impact of both soils and construction.

Lastly, the findings made in this study, and any other future study on urban subsidence, should be accompanied with proper validation. Even if GPS measurements are not available in a city over a longer time, the spatial findings should be tested for plausibility by observations in the field. For example, cracks or leaning buildings can confirm the presence of subsidence as predicted by the radar data, and differences between floor heights and street heights can be measured, as demonstrated by Anh et al. (2019).

When the indications presented in this study can be confirmed and refined in the suggested ways, information of surface subsidence can be used to develop adapted strategies to protect civil habitation and cultural heritage against flash floods and sea level rise in the coastal area of the Thua Thien-Hue province.

\section{Acknowledgements}

This work was conducted within the research project "FloodAdaptVN" funded by the German Ministry of Education and Research (BMBF, grant identifiers 01LE1905C \& 01LE1905A). Sentinel-1 data was provided by the European Space Agency within the Copernicus Programme.

\section{References}

[1] Anh, N. D., Cuong, T. Q., van Anh, T., The, H. A., Thanh, N. T., \& Thang, N. H. (2019). Application TerraSAR-X data for studying land subsidence in Hanoi City. Vietnam Journal of Earth Sciences, 41(4), 339-357. https://doi.org/10.15625/0866-7187/41/4/ 14236

[2] Catalao, J., Raju, D., \& Nico, G. (2020). InSAR maps of land subsidence and sea level scenarios to quantify the flood inundation risk in coastal cities: The case of
Singapore. Remote Sensing, 12(2), 296. https://doi. org/10.3390/rs12020296

[3] Dang, V. K., Doubre, C., Weber, C., Gourmelen, N., \& Masson, F. (2014). Recent land subsidence caused by the rapid urban development in the Hanoi region (Vietnam) using ALOS InSAR data. Natural Hazards and Earth System Sciences, 14(3), 657. https:// doi.org/10.5194/nhess-14-657-2014

[4] Delgado Blasco, J. M., \& Foumelis, M. (2018). Automated SNAP Sentinel-1 DInSAR processing for StaMPS PSI with open source tools: Zenodo. Retrieved from https://zenodo.org/record/1322353

[5] Erkens, G. [Gilles], Bucx, T., Dam, R., Lange, G. de, \& Lambert, J. (2015). Sinking coastal cities. Proceedings of the International Association of Hydrological Sciences, 372, 189-198. https://doi.org/10.5194/ piahs-372-189-2015

[6] Ferretti, A., Prati, C., \& Rocca, F. (2001). Permanent scatterers in SAR interferometry. IEEE Transactions on Geoscience and Remote Sensing, 39(1), 8-20.

[7] Fisher, R. (1954). The analysis of variance with various binomial transformations. Biometrics, 10(1), 130139.

[8] Gambolati, G., Teatini, P., \& Ferronato, M. (2005). Anthropogenic land subsidence. In M. G. Anderson \& J. J. McDonnell (Eds.), Gale virtual reference library. Encyclopedia of hydrological sciences (Vol. 29). Hoboken, N.J.: John Wiley \& Sons. https://doi.org/ 10.1002/0470848944.hsa164b

[9] Hao, Q. N., \& Takewaka, S. (2019). Detection of land subsidence in Nam Dinh coast by DInSAR analyses. In APAC 2019 (pp. 1287-1294). Springer.

[10] Hien, H. M., Trung, T. N., Looijen, W., \& Hulsbergen, K. (2005). Flood Vulnerability Analysis and Mapping in Vietnam. In E. M. Fendel, P. J. M. van Oosterom, \& S. Zlatanova (Eds.), Geo-information for disaster management (pp. 67-83). Berlin, New York: Springer. https://doi.org/10.1007/3-540-27468-5_6

[11] Holzer, T. L. (1984). Preface. In T. L. Holzer (Ed.), 6. Man-induced land subsidence (pp. ix-x). Geological Society of America.

[12] Hooper, A., Bekaert, D., Ekbal, H., \& Spaans, K. (2018). StaMPS/MTI manual: Version 4.1b. Retrieved from https://github.com/dbekaert/StaMPS/blob/master/M anual/StaMPS_Manual.pdf

[13] Hooper, A., Zebker, H., Segall, P., \& Kampes, B. (2004). A new method for measuring deformation on volcanoes and other natural terrains using InSAR persistent scatterers. Geophysical Research Letters, 31(23).

[14] Kaneko, S., \& Toyota, T. (2011). Long-Term Urbanization and Land Subsidence in Asian Megacities: An Indicators System Approach. In M. Taniguchi (Ed.), Groundwater and subsurface 
environments: Human impacts in Asian coastal cities (Vol. 28, pp. 249-270). New York: Springer. https:// doi.org/10.1007/978-4-431-53904-9_13

[15] Karegar, M. A., Dixon, T. H., Engelhart, S. E., Pope, J., \& Kusche, J. (2018). Coastal subsidence: Harbinger of future flooding? Insights from geodesy and geology. In 20th European Geosciences Union General Assembly, Vienna, Austria.

[16] Ketelaar, V. B. H., Abrams, M., Curran, P., Dekker, A., Gomarasca, M. A., Hallikainen, M., ... Parlow, E. (2009). Satellite radar interferometry: Subsidence monitoring techniques. Remote Sensing and Digital Image Processing: Vol. 14. Dordrecht: Springer Netherlands. Retrieved from http://site.ebrary.com/ lib/alltitles/docDetail.action?doclD=10289723 https://doi.org/10.1007/978-1-4020-9428-6

[17] Le, T., Chang, C.-P., Nguyen, X., \& Yhokha, A. (2016). TerraSAR-X data for high-precision land subsidence monitoring: A case study in the historical centre of Hanoi, Vietnam. Remote Sensing, 8(4), 338. https:// doi.org/10.3390/rs8040338

[18] Minderhoud, P. S.J., Erkens, G. [G.], Pham, V. H., Bui, V. T., Erban, L., Kooi, H., \& Stouthamer, E. (2017). Impacts of 25 years of groundwater extraction on subsidence in the Mekong delta, Vietnam. Environmental Research Letters, 12(6), 64006. https://doi.org/10.1088/1748-9326/aa7146

[19] Minh, D., van Trung, \& Toan, T. (2015). Mapping ground subsidence phenomena in Ho Chi Minh City through the radar interferometry technique using ALOS PALSAR data. Remote Sensing, 7(7), 8543-
8562. https://doi.org/10.3390/rs70708543

[20] Nguyen, Q. T. (2016). The main causes of land subsidence in Ho Chi Minh City. Procedia Engineering, 142, 334-341. https://doi.org/10.1016/j.proeng. 2016.02 .058

[21] Snedecor, G. W., \& Cochran, W. G. (1967). Statistical methods (6th ed., Vol. 129): Iowa State University Press.

[22] Strozzi, T., Wegmuller, U., Tosi, L., Bitelli, G., \& Spreckels, V. (2001). Land subsidence monitoring with differential SAR interferometry. Photogrammetric Engineering and Remote Sensing, 67(11), 1261-1270.

[23] Takagi, H., Thao, N., \& Le Anh (2016). Sea-Level Rise and Land Subsidence: Impacts on Flood Projections for the Mekong Delta's Largest City. Sustainability, 8(9), 959. https://doi.org/10.3390/su8090959

[24] Thu, T. M., \& Fredlund, D. G. (2000). Modelling subsidence in the Hanoi City area, Vietnam. Canadian Geotechnical Journal, 37(3), 621-637. https://doi.org/ 10.1139/cgj-37-3-621

[25] Tien Thanh, N., \& Dutto Aldo Remo, L. (2018). Projected changes of precipitation idf curves for short duration under climate change in central Vietnam. Hydrology, 5(3), 33.

[26] Tukey, J. W. (1949). Comparing individual means in the analysis of variance. Biometrics, 99-114.

[27] Zebker, H. A., \& Villasenor, J. (1992). Decorrelation in interferometric radar echoes. IEEE Transactions on Geoscience and Remote Sensing, 30(5), 950-959. 